\title{
SEMICARBAZIDE DIMINISHES THE SIGNS OF BLEOMYCIN-INDUCED PULMONARY FIBROSIS IN RATS
}

\author{
O. O. HUDKOVA ${ }^{\bowtie}$, I. P. KRYSIUK, T. O. KISHKO, \\ N. M. POPOVA, L. B. DROBOT, N. V. LATYSHKO \\ Palladin Institute of Biochemistry, National Academy of Sciences of Ukraine, Kyiv; \\ $e$-mail: ogudkova@biochem.kiev.ua
}

Received: 16 July 2021; Accepted: 22 September 2021

The pathogenesis of pulmonary fibrosis (PF) is accompanied by extracellular matrix (ECM) deposition, oxidative stress, and inflammation progression, as well as hyperactivation of amine oxidases (AOs), which contribute to disease manifestation. The present study aims to elucidate the effect of semicarbazide (SC), an inhibitor of Cu-containing AOs: lysyl oxidase (LOX), semicarbazide sensitive amine oxidase (SSAO), diamine oxidase (DAO), on PF induced in rats by bleomycin (BLM). Eighteen male Wistar rats were randomly divided into four groups: Control, rats of BLM group received BLM (5 $\mathrm{mg} / \mathrm{kg}$, intratracheally once), BLM+SC group obtained $0.005 \%$ solution of SC (about $50 \mu \mathrm{g}$ per capita per day) for three weeks starting immediately after BLM injection, and the Control $+S C$ group drank the same solution as BLM+SC group. The content of cross-linked collagen in total bronchi and free radicals in lung, activities of LOX, SSAO, DAO, polyamine oxidase (PAO), Cu, Zn-superoxide dismutase (SODI), catalase (CAT) and glutathione peroxidase (GPx) in lung and blood were measured. BLM injection induced PF that was confirmed histologically and morphometrically as well as by the elevation of the content of cross-linked collagen and free radicals. The activities of LOX and SSAO involved in post-translational modification of ECM and inflammation were significantly increased $(P<0.05)$. The activities of DAO, and PAO that control polyamine metabolism were also essentially raised. Among antioxidant enzymes, only GPX was activated in the BLM group as compared to control. These changes were absent in the BLM+SC group. SC intake promoted the fact that the histology and morphometric parameters of lung tissue, the content of cross-linked collagen in the bronchi and free radicals in the lung, as well as the activity of the studied enzymes remained at the control level. Our data suggest that SC suppresses the development of BLM-induced PF by inhibiting AOs activities.

Keywords: pulmonary fibrosis, bleomycin, amine oxidases, redox state, antioxidant enzymes, semicarbazide.

$\mathrm{P}$ ulmonary fibrosis (PF) is a chronic progressive interstitial inflammatory disease characterized by tissue scarring and a violation of its architecture that leads to impaired lung function. Although precise molecular mechanisms involved in the pathogenesis of PF are not fully understood, the epithelial-mesenchymal transition (EMT) and imbalance in ROS production are recognized as the essential ones. Both processes are responsible for fibrotic extracellular matrix (ECM) deposition and its modification and, in addition, mutually regulate each other [1].
Excessive amounts of ROS resulting in oxidative stress are especially contributing to this pathology because the lungs are directly exposed to higher oxygen tensions than other organs [2]. Amine oxidases are source of oxidative, carbonyl and nitrosative stresses simultaneously that determines their important metabolic roles under PF manifestation $[3,4]$. At the same time, the regulatory relationship between their functional activity and molecular components of the redox system that underlie this pathology is poorly understood.

(C) 2021 Hudkova O. O. et al. This is an open-access article distributed under the terms of the Creative Commons Attribution License, which permits unrestricted use, distribution, and reproduction in any medium, provided the original author and source are credited. 
Lysyl oxidase (LOX, EC 1.4.3.13) and semicarbazide sensitive amine oxidase (SSAO, EC 1.4.3.21) are involved in the post-translational modifications of collagen, the main structural component of ECM, potentially being essential participants in the pathogenesis of PF $[3,5]$. Pathological destruction of ECM leads to impaired gaseous exchange and exacerbates the observed inflammatory environment, namely the adhesion of leukocytes, in the lungs as a factor contributing to the development of PF. The involvement of SSAO, also identified as vascular adhesion protein-1 (VAP-1), in leukocyte extravasation was confirmed [6]. Moreover, the lung mucosa is a site under the control of inflammatory mediator histamine [7], degradation of which is mediated by the plasma enzyme diamine oxidase/histaminase (DAO, EC 1.4.3.22) [8]. Thereby, SSAO/VAP-1 and DAO also play a crucial role in PF. Additionally, DAO together with polyamine oxidase (PAO, EC 1.5.3.11) regulates the metabolism of polyamines (PAs) involved in pulmonary toxicity [9] and, therefore, these AOs also play important role in the pathology.

The above-mentioned enzymes LOX, SSAO, and DAO are members of the copper-containing AOs family. The active site of these enzymes contains a copper ion and a covalently bound redox cofactor represented by trihydroxyphenylalanine quinine (topaquinone, TPQ) in cases of SSAO and DAO or lysine tyrosylquinone (LTQ) in LOX. Protein-derived carbonyl cofactors TPQ and LTQ are formed as a result of post-translational modification of tyrosine or lysine-tyrosine residues, respectively, near the active site through its own transition in a $\mathrm{Cu}^{2+}$-dependent manner and contain one or two carbonyl groups. Thus, Cu-containing AOs are sensitive to semicarbazide (SC), carbonyl poison, a compound capable of accepting aldehydes and ketones, and known as an inhibitor of these enzymes [4].

There are data that LOX inactivation with an inhibitor or downregulation of its expression level suppressed EMT and significantly reduced PF features $[5,11]$. Therefore, inhibition of $\mathrm{Cu}$-containing AOs, LOX, SSAO, and DAO, particularly resulting in the reduction of collagen cross-linking and excessive ROS production may be an effective strategy to suppress lung tissue fibrosis progression.

Based on the foregoing, the aim of this work was to study the role of $\mathrm{Cu}$-containing $\mathrm{AOs}$ in the development of PF using SC by means of a complex biochemical, histological and morphometric analysis of tissues in rats with bleomycin-induced pathology [12].

\section{Materials and Methods}

Materials. Bleomycin C, phenylmethylsulfonyl fluoride, pargiline hydrochloride, sodium diethylditiocarbamate trihydrate, sodium azide, semicarbazide hydrochloride, methylamine hydrochloride, putrescine hydrochloride, spermine hydrochloride, 1,5-diaminopentan (cadaverine), pepsin from porcine gastric mucosa, Bradford reagent were obtained from Sigma, USA. All other reagents/chemicals were of the highest analytical grade available.

Animals. All manipulations with animals were performed in accordance with European Convention for the protection of vertebrate animals used for experimental and other scientific purposes (Strasbourg, 1986) and national requirements for the care and use of laboratory animals. Male Wistar rats weighting approx. $180 \mathrm{~g}$ up to 2 months old were maintained on the laboratory pelleted diet.

Experimental model. The animal model of pulmonary fibrosis was induced by intratracheal introduction of bleomycin C (BLM) accordingly to [12]. 18 male Wistar rats were divided into 4 experimental groups: Control - intact animals $(n=4)$; BLM animals that received BLM once intratracheally at a dose of $5 \mathrm{mg} / \mathrm{kg}$ body weight $(n=4)$; BLM+SC - animals that received SC at a concentration of $0.005 \%$ with drinking water for 3 weeks starting immediately after BLM injection $(n=7)$; Control+SC - intact animals that received $\mathrm{SC}$ at the same concentration with drinking water simultaneously with $\mathrm{BLM}+\mathrm{SC}$ group (positive control) $(n=3)$. The daily dose of SC was about $50 \mu \mathrm{g}$ per animal $(0.25 \mathrm{mg} / \mathrm{kg})$, which is $1 / 1000$ of the $\mathrm{LD}_{50}$ of SC $(225 \mathrm{mg} / \mathrm{kg})$ and was lower $\mathrm{SC}$ concentration for lathyrism induction which is $1 / 20$ of the $\mathrm{LD}_{50}$ of $\mathrm{SC}(11.4 \mathrm{mg} / \mathrm{kg})$.

Sample collection and preparation of lung cell fractions. After 3 weeks of fibrosis induction, all animals were sacrificed by decapitation under nembutal anaesthesia and blood was collected in tubes with and without heparin. Heparinized blood was immediately centrifuged at $1,500 \times \mathrm{g}$ for $10 \mathrm{~min}$ to separate plasma for the further studies. The resulting plasma was stored at $-20^{\circ} \mathrm{C}$ until analysis of xanthine oxidase (XO), PAO and SSAO activity (up to $24 \mathrm{hrs).}$ The upper lobe of the right lung was extracted and placed on ice. All further steps were performed at $0-4^{\circ} \mathrm{C}$. The left lung was soaked in formalin solution and processed for embedding in paraffin. The lower lobe of the right lung, liver and whole blood samples (without heparin) were frozen in liquid nitrogen for subsequent assays by EPR spectrometry. 
Lung cell fractions were prepared by differential centrifugation as described earlier [13]. Cell fractions obtained from lung tissue were used for fluorometric and spectrophotometric enzymatic assays using microplate riders $\mathrm{FL} \times 800$ and $\mu \mathrm{Quant}$ (USA). Heparinized blood was separated to plasma and erythrocyte mass by centrifugation (at 1,000$2,000 \times \mathrm{g}$ for $10 \mathrm{~min}$ ). The plasma obtained was stored at $-20^{\circ} \mathrm{C}$ until analysis (up to $24 \mathrm{hrs}$ ). After plasma and white platelet collection, erythrocytes were washed twice with PBS $(0.015 \mathrm{M}$ potassium phosphate buffer pH 7.2 containing $0.15 \mathrm{M} \mathrm{NaCl}$ ) and lysed with 5 volumes of ice-cold double-distilled water. Erythrocytes lysates were purified by ethanolchloroform method to get rid of haemoglobin [14] for estimation of the activities of catalase (CAT) and superoxide dismutase (SOD1).

Histological and morphological studies. Fixed lung tissues were processed routinely (fixed in Buen's fluid, dehydrated in alcohols of increasing concentration (from $70^{\circ}$ to $96^{\circ}$ ) and dioxane), embedded in paraffin wax and sectioned $(4 \mu \mathrm{m})$ for Van Gieson's staining. Painted sections were enclosed in Canada balsam [15] and evaluated using Nicon microscope (Japan) equipped with spot digital camera. Morphometry was carried out by means of the computer program 'IMAGE J'.

Extraction of bronchi Collagen. For collagen extraction the isolated bronchi of rats were cut into small pieces, pretreated with $0.3 \mathrm{M} \mathrm{Na}_{2} \mathrm{HPO}_{4}$ (the solid/solution ratio $1: 5(\mathrm{w} / \mathrm{v}))$ and stirred on a magnetic stirrer for $10 \mathrm{~h}$ to remove non-collagenous proteins, followed by centrifugation at $900 \times \mathrm{g}$ for $15 \mathrm{~min}$ at room temperature. The supernatant fraction was discarded. The procedure was replicated three times. Samples were washed with cold distilled water in stirring condition at $4^{\circ} \mathrm{C}$ for 2 h., reaching neutral $\mathrm{pH}$ values of the wash water. The precipitate, washed from proteins of non-collagen nature, was poured with $0.1 \mathrm{M}$ sodium-citrate buffer $\mathrm{pH} 3.6$ containing 3,200 pepsin units/mg ( $4 \mathrm{mg} / \mathrm{ml}$ buffer), and extraction was carried out for 3 days after centrifugation at $3,200 \times \mathrm{g}$ for $10 \mathrm{~min}$ at $4^{\circ} \mathrm{C}$. The precipitate was discarded whereas supernatant with collagen solution was dialyzed against $0.01 \mathrm{M} \mathrm{Na}_{2} \mathrm{HPO}_{4}$ for 1-3 days. The quantitative determination of total collagen, as well as its soluble and insoluble forms, was carried out according to the content of hydroxyproline in accordance with Zaides [16, 17].

EPR spectrometry. Lung, liver tissue and whole blood from each animal were subjected to EPR spectrometry at the temperature of liquid nitrogen with radiospectrometer (Varian E 109, USA) to determine free radicals and cytochrome P450 (CYP450) content. Instrument settings were as follows: range of the magnetic field - 0-3750 Gs; modulation amplitude of the magnetic field - 8 Gs (2 Gs for free radicals); modulation frequency of the magnetic field $100 \mathrm{kHz}$; microwave power $5 \mathrm{~mW}(0.2 \mathrm{~mW}$ for free radicals); microwave frequency (9.6-9.9) GHz.

Assay for AOs activity. Fluorometric assay was used to estimate activity of all AOs under the investigation (SSAO, DAO, PAO and LOX). The method is based on the formation of an intense fluorophore between folic acid and hydrogen peroxide released during the oxidation of the corresponding amine as a substrate $[18,19]$.

Assay for Cu,Zn-superoxide dismutase (SODI EC 1.15.1.1) activity. SOD1 activity was measured as described earlier [20]. The luminol-enhanced chemiluminescence was monitored for 3-5 min at $460 \mathrm{~nm}$ $\lambda_{\text {em }}$ with microplate reader FLx800 (Biotek, USA). The amount of protein required to inhibit the rate of the superoxide anion-induced chemiluminescence of luminol by $50 \%$ was defined as 1 unit of enzyme activity.

Assay for catalase (CAT, EC 1.11.1.6) and glutathione peroxidase (GPx, EC 1.11.1.9) activity. The activities were assessed as was published earlier [20].

Assay for xanthine oxidase (XO, EC 1.17.3.2). The activity of XO was determined as before [20] and was expressed as the amount of uric acid (UA) produced per $1 \mathrm{mg}$ of protein per minute.

Protein concentration. The protein concentration was determined by Bradford method with bovine serum albumin as a standard [21].

Data analysis. Statistical processing of the results was carried out using Excel 2007 and the Statistica 4.5 for Windows software. Shapiro-Wilk test was used for the assessment of normality. Data were analyzed with parametric Student's $t$-test. Results were expressed as mean \pm SEM and significance was set at $P<0.05$.

\section{Results and Discussion}

The most widely used drug for the induction of experimental PF, BLM, which is a glycosylated linear peptide antibiotic produced by the bacterium Streptomyces verticillus, was applied in the experiment.

It should be noted that currently, there is no effective therapeutic strategy for preventing and treating this pathology [22]. The aim of the present 
study was to evaluate the potential antifibrotic and anti-inflammatory activity of the carbonyl compound SC, an inhibitor of Cu-containing amine oxidases, in BLM-induced PF in rats. First and foremost, an effective yet safe daily dose of $0.005 \%$ in drinking water $(0.25 \mathrm{mg} / \mathrm{kg}) \mathrm{SC}$ was selected based on the available literature data obtained on animal models and our previous results from in vivo/in vitro experiments [23-25]. Non-toxicity of applied SC concentration was confirmed by measurement of the total content of hepatic xenobiotic-utilizing cytochromes P450 (CYP450) in rat by EPR. On day $21^{\text {st }}$ after induction of PF in rats with BLM, we did not find significant changes in the content of CYP450 in intact animals consuming SC during this time (control+SC) compared to control, as well as in the BLM+SC group while this indicator was increased (by $30 \%$ ) in animals treated with BLM, compared to control (Fig. 1).

Evaluation after euthanasia included assessment of histopathology and lung morphology. To characterize the state of the tissue, microscopic observations were performed, images of stained samples were obtained, and a morphometric analysis of the lung tissue was carried out.

We found lung tissue with normal architecture in the Control and Control+SC groups. According to data obtained, interalveolar septa were thin, alveoli, alveolar sacs looked clear and noticeable, and there were normal pulmonary vessels and a normal distribution of fibrous tissues (Fig. 2, A). At the same time, in all studied animals receiving BLM, exten-

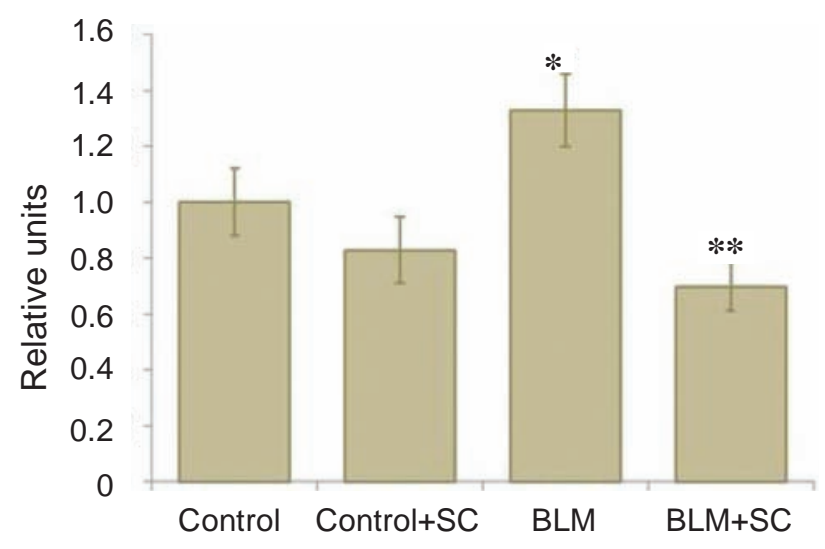

Fig. 1. The cytochromes P450 content in liver from rats with $P F$ induced by BLM with or without semicarbazide (SC) intervention ( $M \pm m, n=3-7)$. $* P<0.05$ compared to Control, $* * P<0.05 \mathrm{com}-$ pared to BLM sive areas of fibrosis were observed with a high degree of variability in individual animals in terms of the severity of fibrosis. Fibrous lesions in animals with advanced pathology were characterized by thickening of the alveolar septum, partially enlarged and rarefied alveoli, and a decrease in the percentage of alveolar air area, which was also manifested in a decrease in the width of the lumen of the respiratory bronchioles, alveolar ducts, and other sacs. These findings indicate a decrease in the gas exchange function of the lungs. Samples from animals treated with BLM also showed infiltration near blood vessels (Fig. 2, A). In contrast, increased airiness of respiratory bronchioles, alveolar ducts and sacs was revealed in samples from animals BLM+SC compared with the BLM group. In addition, less diffuse alveolar damage was observed as well as infiltration foci of different sizes were identified in some sections of lung tissue. Thus, we can conclude that animals receiving SC have less histopathological evidence of acute lung injury (Fig. 2, A).

Morphological analysis of digitized images of stained samples revealed the absence of any morphologic changes in lung from Control+SC animals compared to Control (Table 1). On the contrary, lung tissue samples of BLM-treated rats showed significant deviations associated with fibrosis development: a significant decrease in average diameter of the alveolar lumen and alveolar depth in 1.34 times, the width of the entrance to the alveoli by 1.76 times, as well as the square of the cross-sectional area of the alveoli by 2-fold compared with the parameters of the control group (Table 1). A quantitative morphological evaluation of rat lung samples from $\mathrm{BLM}+\mathrm{SC}$ demonstrated statistically significant positive changes compared to the BLM group: enlargement of the average diameter of the alveolar lumen, depth and width of an entrance to the alveoli up to control values, and doubling the cross-sectional area of the alveoli (Table 1).

Thus, on day 21 post-administration of BLM, histological (Fig 2, A) and computer-assisted morphometric data (Table 1) confirm the development of fibrosis in the rat lung. At the same time, the SC at a selected safe dose, verified by EPR results on the content of liver cytochromes P-450, rendered antifibrotic and anti-inflammatory effects.

The disruption of normal tissue architecture after BLM administration (Fig. 2, B) was related to collagen composition changes in airways (bronchi). Quantitation of collagen by measuring of hydroxy- 


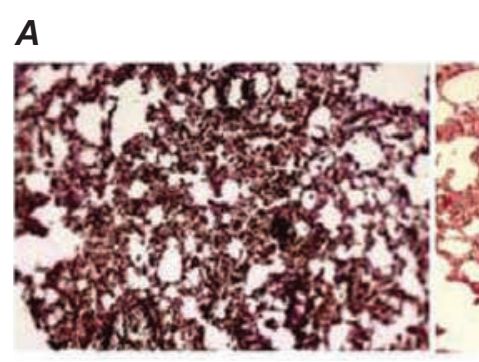

Control

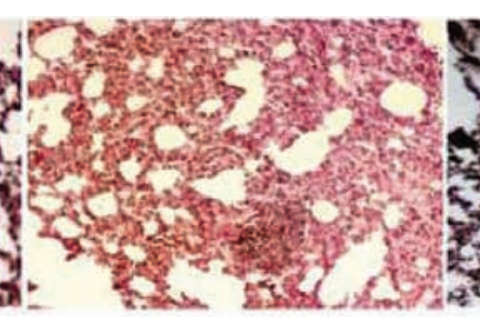

Control+SC

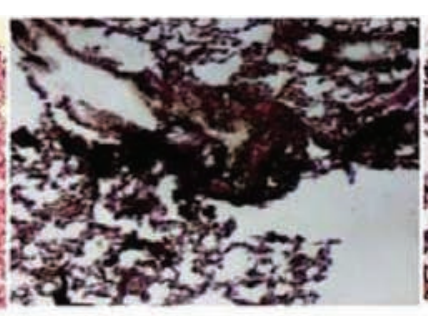

BLM

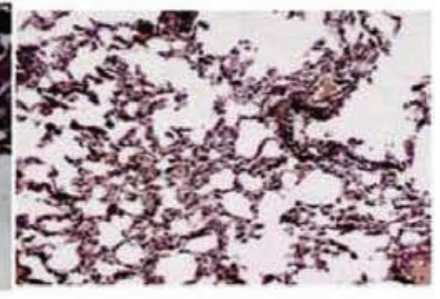

$\mathrm{BLM}+\mathrm{SC}$
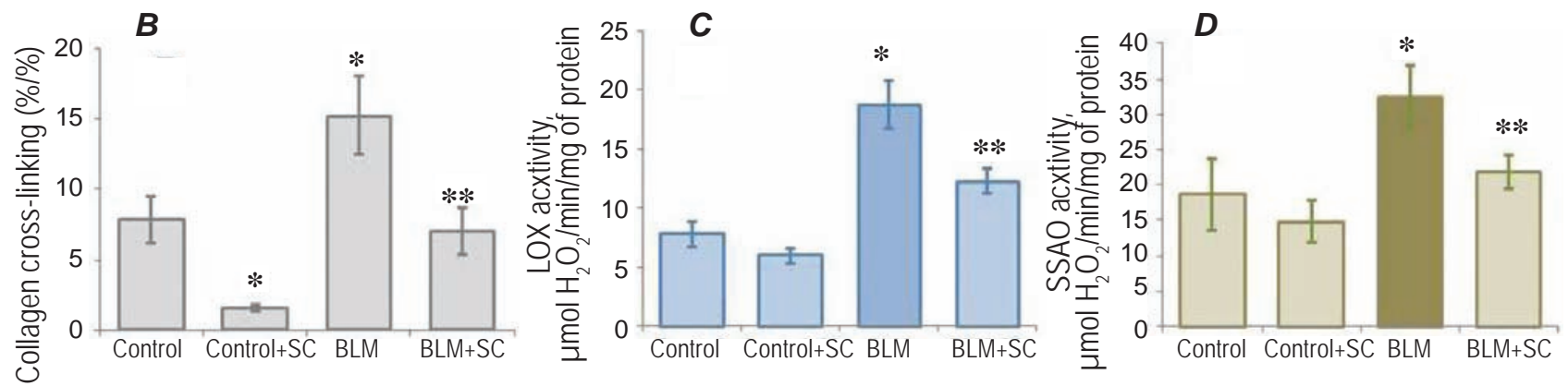

Fig. 2. A - Morphological analysis of lung sections stained with $H \& E$ (the representative photographs are presented); $\boldsymbol{B}$ - the degree of collagen cross-linking, $\boldsymbol{C}$-lysyl oxidase (LOX) and $\mathbf{D}$-semicarbazide sensitive amine oxidase (SSAO) activities in lung tissue structures (parenchyma and airways) from bleomycin-treated rats with or without semicarbazide intervention ( $M \pm m, n=3-7)$ ( $*$ P to Control $<0.05$, **P to BLM $<0.05$ )

proline content revealed elevation of the percentage of intermolecular cross-linked collagen fraction in total bronchi collagen that is associated with fibrosis development [26]. Variations in the collagen content/ composition in the lung tissue structures (airways) under fibrosis have suggested an important role for this protein in pathology development. The intake of SC solution by intact rats resulted in a 3.8-fold decrease in the amount of cross-linked collagen as compared to the control group $(P<0.05)$ (Fig. $2, B)$. This parameter in rats of the $\mathrm{BLM}+\mathrm{SC}$ group was decreased more than twice as compared to BLM group and was similar to control levels.
Fibro-destructive processes in the lung tissue were additionally confirmed by determining the levels of AOs activity involved in the formation of ECM and remodelling of the airways such as LOX and SSAO. It was proposed that SSAO may play a detrimental role in the development of pathologies by inducing unwanted cross-linking of ECM proteins, whereas LOX, an enzyme belonging to the same family as SSAO, is the major enzyme involved in this pathway [27]. We actually showed an increase in the activity of lung enzymes after BLM treatment by 2.4 and 1.7 times for LOX and SSAO, respectively, compared to the control $(P<0.05)$

Ta ble 1. Morphometric data in lung tissue from control and bleomycin-treated rats with or without semicarbazide intervention $(M \pm m, n=3-7)$

\begin{tabular}{|c|c|c|c|c|}
\hline Characteristics & Control & Control+SC & BLM & $\mathrm{BLM}+\mathrm{SC}$ \\
\hline $\begin{array}{l}\text { The average diameter of the } \\
\text { alveolar lumen, } \mu \mathrm{m}\end{array}$ & $28.4 \pm 0.9$ & $27.2 \pm 1.1$ & $21.2 \pm 0.8^{*}$ & $24.8 \pm 0.9^{* * * *}$ \\
\hline Alveolar depth, $\mu \mathrm{m}$ & $25.5 \pm 1.3$ & $24.8 \pm 2.6$ & $19.0 \pm 1.1^{*}$ & $24.2 \pm 1.3^{* *}$ \\
\hline Width of an entrance to an alveolus, $\mu \mathrm{m}$ & $15.5 \pm 0.3$ & $17.2 \pm 1.0$ & $8.8 \pm 0.4^{*}$ & $15.5 \pm 0.5^{* *}$ \\
\hline $\begin{array}{l}\text { The cross-sectional area } \\
\text { of the alveoli, } \mu \mathrm{m}^{2}\end{array}$ & $1083 \pm 17$ & $879 \pm 95$ & $536 \pm 13^{*}$ & $657 \pm 17^{*}$ \\
\hline
\end{tabular}

${ }^{*} P<0.05$ to Control; $* * P<0.05$ to BLM 
(Fig. 2, C, D) which correlated with destructive damage of fibrous tissue and proved the important role of these enzymes in the progression of fibrosis. The activities levels of these AOs in the lung of intact animals drinking SC (Control+SC) were unchanged compared to control, whereas these parameters were significantly decreased (1.4- and 1.6-fold, respectively) in the samples from BLM+SC group (Fig 2, $C, D$ ) compared to BLM group. Enhanced collagen cross-linking and hyperactivation of SSAO and LOX in lung tissues of rats with BLM-induced fibrosis also indirectly evidenced EMT engagement in airways remodelling because components of the ECM are among the main signals able to promote EMT [28]. On the other hand, the absence of these parameters changes in the BLM+SC group compared to Control showed that SC positively influences the mentioned processes by inhibiting LOX and SSAO.

Emerging evidence has suggested that ROS play essential role in fibrosis development and there is correlation between fibrosis, EMT and ROS content $[29,2]$. Indeed, the EPR data showed a significant increase in the level of free radicals in the lungs of rats with fibrosis by 1.4 times compared to the control, while there were no significant changes in free radicals in the blood (Fig. 3). Oral intake of SC by intact animals did not change the level of free radicals in the lungs of rats, while in BLM+SC group it decreased to control level as compared to animals of BLM group that indicated suppression of the degree of oxidative stress in the lungs of these animals. There were no significant changes in free radicals level in whole blood samples after SC treatment both in Control+SC and BLM+SC groups vs their controls (Fig. 3).

In addition, we did not find significant changes in the activity of pro- and antioxidant enzymes in the lungs of fibrotic rats (BLM group) compared to controls, with the exception of GPx (1.4-fold increase). Moreover, there was a significant decrease in XO activity by 1.5 times and a corresponding decrease in the level of SOD1 and CAT activities in the blood of these animals to the same extent (Table 2). SC did not induce significant variations in activities of studied pro-/antioxidant enzymes in the lung of intact rats (Control+SC) with the exception of GPx activity elevation (1.3-fold) compared to Control (Table 2). SC also unchanged activities of hydrogen peroxide-utilizing enzymes, CAT and GPx, in the lung but caused a significant multidirectional shift in activities of enzymes regulating $\mathrm{O}_{2}^{-}$concentration.

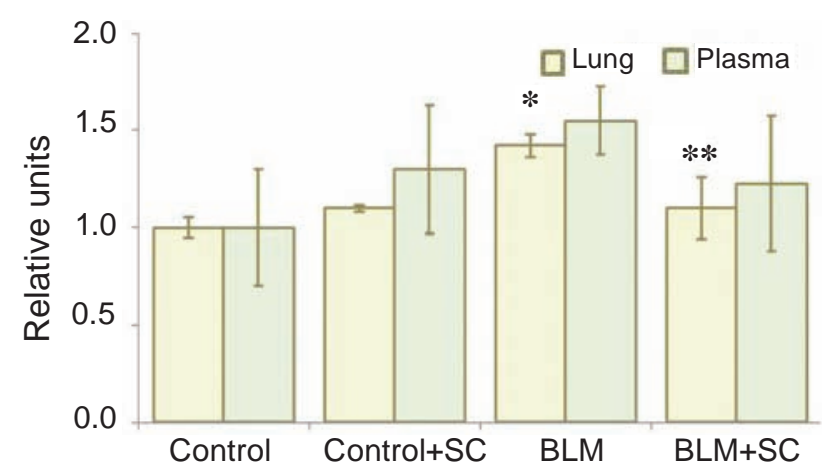

Fig. 3. The level of free radicals in the lungs and plasma in control rats and rats treated with bleomycin, with or without semicarbazide intervention ( $M \pm m, n=3-7, * P<0.05$ to Control, $* * P<0.05$ to $B L M)$

In particular, $\mathrm{XO}$ activity was decreased 2 times and SOD1 activity was increased 1.7-fold in animals with PF $(\mathrm{BLM}+\mathrm{SC})$ compared to control $(P<0.05)(\mathrm{Ta}-$ ble 2). The activities of antioxidant enzymes SOD and CAT in the purified lysates of rat erythrocytes of the Control+SC group decreased by 1.6 and 2.1 times, respectively, as compared to Control and were approximately the same as in the BLM group, while in the BLM+SC group these parameters weren't changed compared to BLM group (Fig. 2).

These results indicate a fairly high degree of development of oxidative stress in the fibrous lung, which is practically not compensated by antioxidant protection, while partial antioxidant protection of this tissue is possibly realized by the functioning of GPx (Table 2). At the same time, SC effectively suppressed the intensity of oxidative stress in the targeted organ through the down-regulation of prooxidant XO and up-regulation of key antioxidant SOD1. Therefore, our data are consistent with the notion that oxidative stress and the antioxidant system in the lung appear to be crucial modulators of PF.

BLM-induced PF is accompanied not only by oxidative stress, which is well known and demonstrated by our present results, but also by carbonyl stress caused by excessive amounts of reactive aldehydes [29]. We assumed a significant contribution of AOs to the development of oxidative stress as a source of ROS. However, there is a relationship and interdependence between ROS and reactive aldehydes, another product of the oxidative deamination reaction, as they reinforce each other, forming a vicious circle. 
Table 2. Activities of pro- and antioxidant enzymes in lung and blood from control and bleomycin-treated rats with or without semicarbazide administration $(M \pm m, n=3-7)$

\begin{tabular}{lcccc}
\hline \multicolumn{1}{c|}{ Enzymatic activities } & Control & Control+SC & BLM & BLM+SC \\
\hline & Lungs & & & \\
$\mathrm{XO}, \mu \mathrm{mol} \mathrm{UA} / \mathrm{min} / \mathrm{mg}$ of protein & $1.03 \pm 0.16$ & $0.61 \pm 0.29$ & $0.89 \pm 0.18$ & $0.52 \pm 0.11^{* * * *}$ \\
$\mathrm{SOD} 1, \mathrm{U} / \mathrm{mg}$ of protein & $286 \pm 37$ & $322 \pm 85$ & $335 \pm 51$ & $485 \pm 85^{*}$ \\
$\mathrm{CAT}, \mu \mathrm{mol} \mathrm{H} \mathrm{O}_{2} / \mathrm{min} / \mathrm{mg}$ of protein & $18.5 \pm 2.5$ & $18.9 \pm 0.8$ & $16.5 \pm 1.2$ & $18.9 \pm 1.2$ \\
$\mathrm{GPx}, \mu \mathrm{mol} \mathrm{H} \mathrm{O}_{2} / \mathrm{min} / \mathrm{mg}$ of protein & $22.9 \pm 2.5$ & $29.7 \pm 2.4^{*}$ & $30.9 \pm 3.0^{*}$ & $24.5 \pm 2.8$ \\
& Blood & & \\
$\mathrm{XO}, \mu \mathrm{mol} \mathrm{UA} / \mathrm{min} / \mathrm{mg}$ of plasma protein & $0.87 \pm 0.18$ & $0.73 \pm 0.25$ & $0.44 \pm 0.10^{*}$ & $0.57 \pm 0.07$ \\
$\mathrm{SOD} 1, \mathrm{U} / \mathrm{mg}$ of protein & $444 \pm 34$ & $269 \pm 45^{*}$ & $286 \pm 35^{*}$ & $242 \pm 33^{*}$ \\
$\mathrm{CAT}, \mu \mathrm{mol} \mathrm{H} \mathrm{O}_{2} / \mathrm{min} / \mathrm{mg}$ of protein & $248 \pm 10$ & $119 \pm 22^{*}$ & $136 \pm 14^{*}$ & $139 \pm 14^{*}$ \\
\hline
\end{tabular}

$* P<0.05$ to Control, $* * P<0.05$ to BLM

Ta ble 3. Activities of amine oxidases in lung and blood from control and bleomycin-treated rats with or without semicarbazide intervention $(M \pm m, n=3-7)$

\begin{tabular}{l|c|c|c|c}
\hline \multicolumn{1}{c|}{ Enzymatic activities } & Control & Control+SC & BLM & BLM+SC \\
\hline \multicolumn{4}{c}{ Lungs } \\
DAO, $\mu \mathrm{mol} \mathrm{H} \mathrm{O}_{2} / \mathrm{min} / \mathrm{mg}$ of protein & $8.35 \pm 1.37$ & $3.99 \pm 1.08^{*}$ & $15.3 \pm 1.2^{*}$ & $6.15 \pm 0.58^{* *}$ \\
$\mathrm{PAO}, \mu \mathrm{mol} \mathrm{H} \mathrm{O}_{2} / \mathrm{min} / \mathrm{mg}$ of protein & $0.35 \pm 0.08$ & $0.52 \pm 0.05$ & $1.20 \pm 0.23^{*}$ & $1.07 \pm 0.14^{*}$ \\
& \multicolumn{3}{c}{ Blood } \\
$\mathrm{SSAO}, \mu \mathrm{mol} \mathrm{H} \mathrm{O}_{2} / \mathrm{min} / \mathrm{mg}$ of protein & $1.29 \pm 0.12$ & $0.92 \pm 0.21$ & $2.27 \pm 0.30^{*}$ & $1.60 \pm 0.24^{* *}$ \\
$\mathrm{PAO}, \mu \mathrm{mol} \mathrm{H} \mathrm{O}_{2} / \mathrm{min} / \mathrm{mg}$ of protein & $0.081 \pm 0.017$ & $0.121 \pm 0.011$ & $0.149 \pm 0.023^{*}$ & $0.150 \pm 0.019^{* * * *}$ \\
\hline
\end{tabular}

$* P<0.05$ to Control, $* * P<0.05$ to BLM

Actually, we found a significant increase in the activities not only LOX and SSAO but also others AOs studied in lung and blood of BLM-treated rats relative to the control. As can be seen from Table 3, activities of enzymes involved in inflammatory processes, DAO in the lung and SSAO in the blood, of fibrotic rats increased to the same extent, 1.8 times, while PAO activity elevated 3.4 times in the lung and 1.4 times in the blood vs control (Table 3). These data suggest that an increase in SSAO activity in the lung may correlate with the infiltration of inflammatory cells into the tissue, while an increase in DAO activity corresponds to high concentrations of the inflammatory mediator, histamine. In addition, the increase in the activity of the soluble form of SSAO is the result of SSAO release from the damaged tissue, in this case the lung, and the aforementioned AOs are involved in PAs degradation.

Accordingly, the observed degree of increase in the activity of PAO is consistent with the Grasemann et al. data showing that there are multiple increases in the concentration of putrescine and to a greater extent spermine, PAO substrates, in the lung of animals with the developed fibrosis [10]. That is, such an increase in the activity of all AOs can be associated with an increase in the synthesis of biogenic amines and polyamines in PF and corresponds to signs of inflammation and destructive tissue changes observed according to the data of histological and morphometric analysis. These data further demonstrated that BLM-induced PF in rats is a suitable experimental model for the analysis of pathological changes and the underlying molecular mechanisms in the development of this system pathology. As we expected, SC significantly lowered the activity of $\mathrm{Cu}$-dependent DAO in the animal lung of both groups treated with SC, Control+SC, and BLM+SC in 2.1 and 2.5-times as compared to Control and BLM, respectively, while the activity of PAO in these groups did not change. Also, the activity of Cu-dependent SSAO in blood decreased in both groups, Control $+\mathrm{SC}$ and $\mathrm{BLM}+\mathrm{SC}$, to the same 
extent 1.4-fold relative to their controls. On the contrary, the PAO activity in this tissue remained unchanged after SC treatment of intact rats compared to the control, and in the BLM + SC group compared to the BLM alone group, it remained 1.84 times higher than in the control. The latter indicates a high concentration of spermine in the blood of fibrotic animals, which causes an increase in the function of PAO according to Grasemann et al [10].

Conclusion. The study of BLM-induced fibrotic changes in the lung of rats, that were weakened by the use of SC, an inhibitor of Cu-dependent AO, made it possible to reveal the important role of AOs in the development of PF. The obtained data contribute to the understanding of the molecular basis of PF and could be useful to the development of new therapeutic approaches to the treatment of this pathology.

Conflict of interest. Authors have completed the Unified Conflicts of Interest form at http://ukrbiochemjournal.org/wp-content/uploads/2018/12/

Funding. The present study was funded by the National Academy of Sciences of Ukraine for $\mathrm{R} \& \mathrm{D}$ on "The role of amine oxidases in the carbonyl/oxidative stress development under different pathologies" (No 0115U003644) and "Mechanisms of regulation of intracellular signaling networks, intercellular and intermolecular interactions" (No 0112U2624).

Acknowledgments. The authors are dedicating this paper to the memory of deceased colleague, leader of our research team Dr. Serhii Shandrenko. We are grateful to him for the study idea, the experiment design, helpful advanced and general leadership of this work. We thank also Dr. T. Volodina for her contribution in the experiment, namely, isolation and quantitative analysis of collagen in bronchi samples.

\section{СЕМІКАРБАЗИД ЗМЕНШУС \\ ОЗНАКИ ІНДУКОВАНОГО БЛЕОМЦИНОМ ФІБРОЗУ ЛЕГЕНІ УЩУРІВ}

О. О. Гудкова ${ }^{\bowtie}$ І. П. Крисюк, Т. О. Кішко, Н. М. Попова, Л. Б. Дробот, Н. В. Латишко

Інститут біохімії ім. О.В. Палладіна
НАН України, Київ;
$\unrhd_{\text {e-mail: ogudkova@biochem.kiev.ua }}$

Характерними ознаками фіброзу легені (ФЛ) вважають накопичення компонентів позаклітинного матриксу (ПКМ), окислювальний стрес та запалення. Крім того, ФЛ супроводжується гіперактивацією аміноксидаз (АО), які суттєво впливають на прогресування цього захворювання. Метою дослідження було з'ясувати вплив семікарбазиду (SC), інгібітора мідьвмісних AO (лізилоксидази (LOX), семікарбазидчутливої амінооксидази (SSAO), діамінооксидази (DAO)), на індукований блеоміцином (BLM) ФЛ у щурів. Вісімнадцять щурів-самців лінії Wistar було розділено на чотири групи: Контроль (інтактні тварини); група BLM - тварини, яким вводили BLM (5 мг/кг) внутрішньотрахеально одноразово; група BLM+SC отримувала $0,005 \%$ розчин SC (приблизно 50 мкг на тварину на добу) протягом трьох тижнів одразу після введення BLM; група Контроль + SC споживала одночасно 3 групою BLM+SC той самий розчин. У тканинах тварин визначали такі показники: вміст зшитого колагену в бронхах та вільних радикалів у легені, активність LOX, SSAO, DAO, поліаміноксидази (РAO), $\mathrm{Cu}, \mathrm{Zn}$-супероксиддисмутази (SOD1), каталази (CAT) та глутатіонпероксидази (GPx) в легені та крові. Введення BLM щурам спричинювало у них розвиток ФЛ, що було підтверджено гістологічно та морфометрично. Роз- 
виток ФЛ також супроводжувався підвищенням вмісту зшитого колагену в бронхах та вільних радикалів в легеневій тканині відносно контролю. Рівні активності LOX та SSAO, які беруть участь у посттрансляційній модифікації ПКМ та запаленні, були значно підвищені в тварин групи BLM $(P<0,05)$. Активності DAO та PAO, які контролюють обмін поліамінів, також істотно зростали. 3 усіх досліджених антиоксидантних ензимів у тканинах тварин із ФЛ зазнавала збільшення порівняно 3 контролем лише активність GPx. Bci описані вище зміни були відсутні в групі BLM+SC. Вживання тваринами SC сприяло тому, що гістологічні та морфометричні показники легеневої тканини, вміст зшитого колагену в бронхах та вільних радикалів у легені, а також активність досліджуваних ензимів залишалися на рівні контролю. Одержані дані свідчать про те, що SC стримує розвиток індукованого BLM фіброзу легені шляхом інгібування АО.

К л ю ч о в і с л о в а: фіброз легені, блеоміцин, амінооксидаза, окисно-відновний стан, антиоксидантні ензими, семікарбазид.

\section{References}

1. Clarke DL, Carruthers AM, Mustelin T, Murray LA. Matrix regulation of idiopathic pulmonary fibrosis: the role of enzymes. Fibrogenesis Tissue Repair. 2013; 6(1): 20.

2. Cheresh P, Kim SJ, Tulasiram S, Kamp DW. Oxidative stress and pulmonary fibrosis. Biochim Biophys Acta. 2013; 1832(7): 1028-1040.

3. Marttila-Ichihara F, Elima K, Auvinen K, Veres TZ, Rantakari P, Weston C, Miyasaka M, Adams D, Jalkanen S, Salmi M. Amine oxidase activity regulates the development of pulmonary fibrosis. FASEB J. 2017; 31(6): 2477-2491.

4. Structure and functions of amine oxidases. (Ed by Mondovi B). CRC Press. 2017. 299 p.

5. Wang J, Zhu Y, Tan J, Meng X, Xie H, Wang R. Lysyl oxidase promotes epithelialto-mesenchymal transition during paraquatinduced pulmonary fibrosis. Mol Biosyst. 2016; 12(2): 499-507.

6. Salmi M, Jalkanen S. Vascular Adhesion Protein-1: A Cell Surface Amine Oxidase in Translation. Antioxid Redox Signal. 2019; 30(3): 314-332.

7. Lucarini L, Pini A, Rosa AC, Lanzi C, Durante M, Chazot PL, Krief S, Schreeb A, Stark H,
Masini E. Role of histamine H4 receptor ligands in bleomycin-induced pulmonary fibrosis. Pharmacol Res. 2016; 111: 740-748.

8. Branco ACCC, Yoshikawa FSY, Pietrobon AJ, Sato MN. Role of Histamine in Modulating the Immune Response and Inflammation. Mediators Inflamm. 2018; 2018: 9524075.

9. Hoet PH, Nemery B. Polyamines in the lung: polyamine uptake and polyamine-linked pathological or toxicological conditions. Am $J$ Physiol Lung Cell Mol Physiol. 2000; 278(3): L417-L433.

10. Grasemann H, Shehnaz D, Enomoto M, Leadley M, Belik J, Ratjen F. L-ornithine derived polyamines in cystic fibrosis airways. PLoS One. 2012; 7(10): e46618.

11. Cox TR, Bird D, Bake AM, Barker HE, Ho MWY, Lang G, Erler JT. LOX-mediated collagen crosslinking is responsible for fibrosisenhanced metastasis. Cancer Res. 2013; 73(6): 1721-1732.

12. Reinert T, Baldotto CSR, Nunes FAP, Scheliga AAS. Bleomycin-Induced Lung Injury. J Cancer Res. 2013; 2013: 1-9.

13. Latyshko N, Gudkova O, Dmytrenko M. Semicarbazide as potential source of formaldehyde and nitric oxide formation. Drugs Ther Stud. 2012; 2(1): e9.

14. Gudkova OO, Latyshko NV, Gudkova LV, Mikhailovsky VO. Rat liver catalase under artificial hypobiosis conditions. Biopolym Cell. 2005; 21(1): 28-34. (In Ukrainian).

15. Korzhevsky DE, Gilyarov AV. Fundamentals of histological technique. St. Petersburg: SpetsLit. 2010. 96 p. (In Russian).

16. Zaides AL, Mikhailov AN, Pushchenko OI. Modified method for determination of oxyproline. Biochemistry. 1964; 29(1): 5-7.

17. Volodina TT, Dzvonkevych ND, Petrun' LM, Krysiuk IP, Popova NM, Shandrenko SH, Dmytrenko MP. Altered collagene characteristics and lysyl oxidase activity in lathyrism. Fiziol Zh. 2011; 57(3): 62-68. (In Ukrainian).

18. Gudkova OO, Latyshko NV, Shandrenko SG. Amine oxidases as important agents of pathological processes of rhabdomyolysis in rats. Ukr Biochem J. 2016; 88(1): 79-87.

19. Gudkova OO, Latyshko NV, Zaitseva OV, Shandrenko SG. Purification procedure and assay for the activity of lysyl oxidase. $U k r$ Biochem J. 2018; 90(5): 98-105. 
20. Labudzynskyi DO, Zaitseva OV, Latyshko NV, Gudkova OO, Veliky MM. Vitamin $\mathrm{D}_{3}$ contribution to the regulation of oxidative metabolism in the liver of diabetic mice. $U k r$ Biochem J. 2015; 87(3): 75-90.

21. Bradford MM. A rapid and sensitive method for the quantitation of microgram quantities of protein utilizing the principle of protein-dye binding. Anal Biochem. 1976; 72(1-2): 248-254.

22. Zhang CY, Duan JX, Yang HH , Sun CC, Zhong WJ, Tao JH, Guan XX, Jiang HL, Hammock BD, Hwang SH, Zhou Y, Guan CX. COX-2/sEH dual inhibitor PTUPB alleviates bleomycin-induced pulmonary fibrosis in mice via inhibiting senescence. FEBS J. 2020; 287(8): 1666-1680.

23. Maranghi F, Tassinari R, Marcoccia D, Altieri I, Catone T, De Angelis G, Testai E, Mastrangelo S, Evandri MG, Bolle P, Lorenzetti S. The food contaminant semicarbazide acts as an endocrine disrupter: Evidence from an integrated in vivo/in vitro approach. Chem Biol Interact. 2010; 183(1): 40-48.

24. Dmytrenko MP, Shandrenko SH, Petrun LM, Kishko TO, Sylonova NV, Latyshko NV,
Gudkova OO, Sushkova VV. Formaldehyde metabolism in semicarbazide intoxication. Ukr Biokhim Zhurn. 2010; 82(4): 86-91. (In Ukrainian).

25. Bailey AJ, Peach CM, Fowler LJ. Chemistry of the collagen cross-links. Isolation and characterization of two intermediate intermolecular cross-links in collagen. Biochem J. 1970; 117(5): 819-831.

26. Mercier N. The role of 'semicarbazide-sensitive amine oxidase' in the arterial wall. Artery Res. 2009; 3(4): 141-147.

27. Giannoni E, Parri M, Chiarugi P. EMT and oxidative stress: a bidirectional interplay affecting tumor malignancy. Antioxid Redox Signal. 2012; 16(11): 1248-1263.

28. Richter K, Kietzmann T. Reactive oxygen species and fibrosis: further evidence of a significant liaison. Cell Tissue Res. 2016; 365(3): 591-605.

29. Oury TD, Thakker K, Menache M, Chang LY, Crapo JD, Day BJ. Attenuation of bleomycininduced pulmonary fibrosis by a catalytic antioxidant metalloporphyrin. Am J Respir Cell Mol Biol. 2001; 25(2): 164-169. 